\title{
Does the Christian worldview provide a place for the law of attraction? (Part 2): An apologetic evaluation of the way the Bible is used in promoting this idea
}

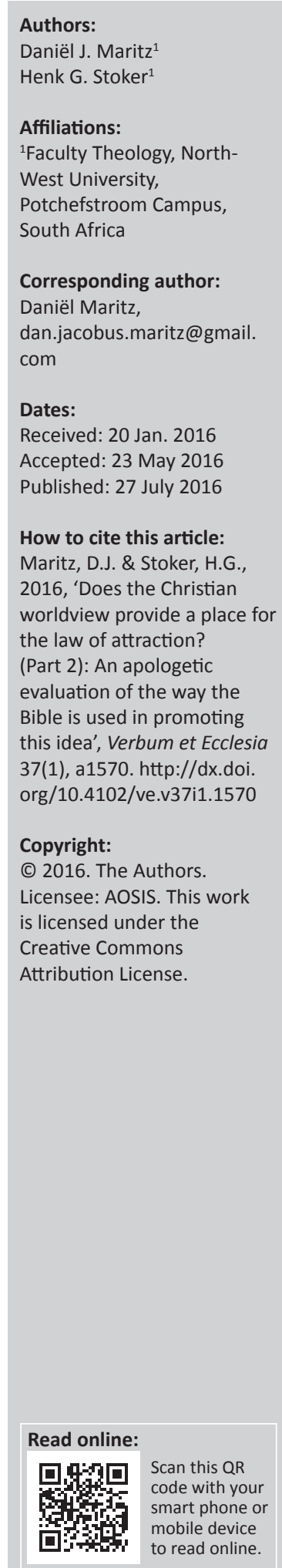

This article investigates the biblical motivation that is given for the secular idea of the so-called spiritual law of attraction to become part of Christian doctrine. In 2010 Pastor At Boshoff of the Christian Revival Church (CRC) preached two sermons on the law of attraction in which he claimed it as a powerful principle in the Word of God. According to him this biblical 'law' provides human beings with physical manifestations of their thoughts and words. The idea to create one's own favourable future through the law of attraction flows from a New Age worldview and is similar to the positive confession doctrine taught by popular Word of Faith teachers. Boshoff's claim regarding the law of attraction cannot be deduced from the key Scripture passages he uses, which reflects an unfounded use of Scripture to promote this idea.

Intradisciplinary and/or interdisciplinary implications: The article challenges the secular infiltration of the Law of Attraction in the church. This is important since the so-called Law of Attraction was preached by Pastor A. Boshoff of the CRC. Many of his listeners embrace his teaching although it reflects a poor exposition and application of Scripture.

\section{Introduction}

This article focuses on the question of whether the Christian worldview ${ }^{1}$ provides a place for the so-called spiritual law of attraction. Pastor At Boshoff of the Christian Revival Church $(\mathrm{CRC})^{2}$ in South Africa is one of the advocates of the law of attraction as an important biblical doctrine. He preached two sermons in 2010, calling it a powerful principle in the Word of God that provides human beings with physical manifestations of their thoughts and words (Boshoff 2010a, 2010d). He sees it as a law that every Christian must take cognition of, because it can be used to one's own benefit or destruction.

The first article about the law of attraction as seen by Pastor Boshoff focused on the roots of this idea. It was found that the law of attraction originated outside of the Christian church in a New Age environment. In this article the teaching of the law of attraction will be tested against what is being taught in the Bible to answer the question whether it is indeed a biblical doctrine ${ }^{3}$.

\section{Preaching the law of attraction: Is it biblical?}

\section{The issue at hand}

Because Pastor Boshoff from the CRC proclaimed the law of attraction as a biblical, and a Christian principle, from the pulpit - especially in two of his sermons in 2010 (Boshoff 2010a, 2010d) - the writers deem it necessary to address this matter. According to the CRC's statement of faith, the CRC believes in the Old and New Testaments of the Bible as the inspired Word of God and the final authority for faith and life (CRC 2015b). This church clearly claims to hold the Scriptures in high regard, as the Christian church throughout the ages did.

1.After discussing the Christian theistic worldview in detail, Sire $(2009: 46)$ comes to the following conclusion of what the Christian theistic worldview is: '... Christian theism is primarily dependent on its concept of God, for theism holds that everything stems from him. Nothing is prior to God or equal to him. He is He Who Is. Thus theism has basics for metaphysics. Since He Who Is also has worthy character and thus The Worthy One, theism has basics for ethics. Since He Who Is also is He Who knows, theism has a basis for epistemology. In other words, theism is a complete worldview'. The Christian worldview always starts with God how he reveals himself and not how we want him to be.

2.Boshoff established the Christian Revival Church (CRC) in 1994 and today the combined membership of the CRC is more than 53000 members (CRC 2015a).

3.This evaluative study will be done from the perspective of the Reformed tradition. The entire discussion will thus assume that Reformed theology, based on the Bible as the infallible Word of God, is the best and most consistent expression of the Christian faith. Our theology, based on the Bible as the infallible Word of God, is the best and most consistent expression of the Christian faith. Our
exegetical approach can be described with the words of article 18 of the Chicago statement (CRTA 2015) on Biblical inerrancy: 'We exegetical approach can be described with the words of article 18 of the Chicago statement (CRTA 2015) on Biblical inerrancy: 'We
affirm that the text of Scripture is to be interpreted by grammatico-historical exegesis, taking account of its literary forms and devices, and that Scripture is to interpret Scripture'. For a brief summary of the Reformed theology one can look at the three forms of unity (The Belgic confession of faith, the Heidelberg Catechism and the Canons of Dort). 
Seeing that the law of attraction was preached from the Bible by Boshoff, the question that must be answered is: Is the law of attraction in accordance to what is being taught in the Bible? Through analysing the two sermons of Boshoff (2010a, 2010d) and searching the Scriptures ${ }^{4}$, it must also be established whether the possible differences in understanding with mainstream Christianity amounts to a struggle between orthodoxy and heresy (see Hanegraaff 2009:14).

This analysis will be a content analysis and it will take the following form: Firstly a broad outline of Boshoff's two sermons will be provided after which his use of Scripture will be evaluated. The evaluation will be done by consulting different commentaries within the Reformed tradition. Finally the dogmatic implications of the law of attraction will be indicated by referring to the Bible and dogmatic sources ${ }^{5}$. Pastor Boshoff used the New King James version (NKJV) of the Bible in his sermons. For comparison and reliability, the same Bible translation will be used in this analysis.

\section{A broad outline of Boshoff's sermons on the law of attraction}

Boshoff (2010a) begins his first sermon on the law of attraction in 2010 by explaining that he wants to talk about a powerful law that governs one's life. He defines this powerful law - the law of attraction - as follows: 'The law of attraction simply says: Like attracts like. You're attracting to yourself who you are'. He elaborates further on this by saying: '... we're creating our own future all the time, whether we like to know it or not' (Boshoff 2010a).

In these sermons he claims that every child of God should always live a blessed life, because the life blessed with goodness is God's highest desire for every Christian. He refers to Bible verses such as Jeremiah 29:11, John 10:10, 1 Corinthians 2:9, Galatians 3:13-14, Ephesians 1:3, 2 Peter 1:3 and 3 John 2 to support this claim. When he refers to 3 John 2, he states that if it is translated literally it would mean to succeed in financial matters. Accordingly, every Christian has already been blessed to live a great and prosperous life in material wealth (Boshoff 2010a). To access this prosperous life one must first understand the working of this law:

Whether you know it or not, whether you like it or not, you're attracting things into your life all the time, good or bad, wanted and unwanted. All the time you are sending out a force, a power, an energy, that either attracts good things and good people into your life, or it repels good things and good people.

After referring to Matthew 12:33-35, Boshoff (2010a, 2010b) explains that some people seem to struggle in life, because they have never allowed the grace of God to change their

4.Then the brethren immediately sent Paul and Silas away by night to Berea. When they arrived, they went into the synagogue of the Jews. These were more fairminded than those in Thessalonica, in that they received the word with all readiness, and searched the Scriptures daily to find out whether these things were so'.

5.This article does not intend to provide a thorough exegesis on the Scriptura references being used by pastor Boshoff. The sermon's appeal to Scripture and interpretations of the texts will be examined for consistency and reliability. interpretations of the texts will be examined for consistency and reliability. Interpretations of specific texts will be tested against the exegetical finding of scholarly Christians from the Reformed tradition (Both recent and in the past). Dogmatic implications will be handled in a similar way. inner treasure. He explains further with regard to these people: 'Although they say the right thing, on the inside they are controlled by something else, and that something else all the time is sending out an invisible signal'.

According to Boshoff (2010d), it is the thoughts of human beings that limit their life and one must somehow enlarge oneself on the inside. He makes it clear that one's biggest enemy is nothing or nobody else than what one allows to go on in one's heart, mind and thoughts. That seems to be the place where one can neutralise oneself:

Notice that the Bible says what is in your heart you're attracting into your life all the time, whether you like it or not. You live by the simple law of attraction. All the time you're attracting things into your life, good or bad, wanted or unwanted. You attract what is at the core of your heart. (Boshoff 2010d)

Boshoff (2010b) also refers to Proverbs 4:23 to assert that, whatever one hold in one's heart, one will attract into one's life. It is from within that one constantly releases some kind of energy that attracts things and people to oneself. He writes:

So whatever you think about all the time you're attracting in your life all the time. Whatever you give your energy and whatever you put your focus upon you're attracting to yourself all the time. (Boshoff 2010b)

According to Boshoff (2010b) one's heart was created by God to produce one's future. He describes it as the soil that brings forth whatever one put in it and this is then the reason why the Bible says one must guard it more than anything else. One's heart is consequently releasing and attracting things, people and circumstances into one's life (Boshoff 2010c).

When Boshoff (2010c) turns to Genesis 39:2-4, he directly connects the favour that Joseph found in the sight of his master to the law of attraction. Joseph supposedly attracted this favour because he believed in the good will of God for his life. Boshoff (2010c) applies this to his listeners by explaining that they can also attract favour to themselves if they believe.

With all this said, Boshoff $(2010 a, 2010 c)$ has to admit that, to a certain extent, there are tribulations in one's life that are beyond one's control. He vividly refers to Psalm 27:3 and 13, Psalm 23:1, 4 and 6 and Psalm 30:5 to motivate this. Following these verses he explains that one must always expect good things in bad situations. In the light of the whole message of his sermons on the way the law of attraction works, these comments seem to be in contradiction with what was explained, and it raises inevitable questions.

\section{Evaluating Boshoff's use of Scripture}

\section{Do Proverbs 4:23 and 23:7 support the law of attraction?}

Two key Scripture texts that Boshoff (2010b) uses to support the law of attraction are from the book of Proverbs. The first one is Proverbs 4:23 which reads: 'Keep your heart with all diligence, for out of it spring the issues of life' (Bible 1982). 
When reading Proverbs 4:23, it must be remembered that in wisdom literature the 'heart' is considered to refer to the innermost being of humankind. It does, not refer to the physical organ inside the human body, but rather to human moral based thoughts and feelings, or as Lange et al. (2008:73) describe it: 'the pure moral consciousness of man ...' (Garret 1993:88; Keil \& Delitzsch 1996:82; Murphy 1998:28).

The heart as one's innermost being is in a figurative sense portrayed in Proverbs 4:23 as a water source from which life erupts in a figurative sense (Longman 2006:154; Murphy 1998:28). As the wellspring of life, true joy comes from within and not from circumstances (Garret 1993:88). A truly meaningful life can be described as the spiritual vitality which wells up as truth, is made man's own, and flows abroad wherever his renewed outlook makes itself felt (Kidner 1964:65). It is sufficient to state that the heart as one's intellectual, and especially moral and emotional centre, will determine one's everyday approach to life. A person with a bad heart will sooner or later reflect badness in his or her everyday life (Keil \& Delitzsch 1996:82). The verb 'spring' in Proverbs 4:23 can hardly refer to the heart's ability to attract or repel things into or from one's life. Boshoff's (2010b) remark regarding Proverbs 4:23, namely, 'Whatever is in your heart you're attracting into your life', is not consistent with the picture that is being used in this verse and is foreign to this passage.

Proverbs 4:10-27 portray the biblical metaphor of comparing two paths with each other (see also Mt 7:13-14). It is the path of the wicked and the path of the righteous which serve as a metaphor to compare the behaviour, lifestyles and fate of these two paths (VanGemeren 1997:1097). The heart as the intellectual, moral and emotional centre, will determine the path someone will follow, but that does not mean that the heart literally produce one's future by attracting people, things or circumstances as Boshoff (2010b) is teaching 6 . Proverbs 4:23 can thus not be used in a consistent and reliable way to support the law of attraction.

The other key Scripture text that Boshoff (2010b) uses from Proverbs to support the law of attraction is Proverbs 23:7. After listing a couple of negative thoughts and referring specifically to Proverbs 23:7, Boshoff (2010b) says:

If you're thinking those negative thoughts all the time you are releasing a negative energy from your heart that repels good things from you. It's like you have this invisible shield that repels and whatever you fear you begin to bring into your life.

Proverbs 23:7 is a difficult Scriptural reference to work with. When dealing with this verse, both Keil and Delitzsch (1996:339) and Murphy (1998:173) emphasise that the translation of the first phrase in this verse is difficult and

6.Longman (2006:154) describes it as follows: "The father is not interested in just superficial response from his son, some kind of behaviour modification; he desires supe his response that his child be wise at his very core. Action and speech will flow from a wise character. Verse 22 gives motivation to the son to pay attention to his father. If $h$ takes the message to heart, then that will lead to a life wholeness ... It is most important that the son preserves the integrity of his heart. It is from the heart that life derives. The father is not speaking literally. The heart can remain beating, but person be dead in other ways. An evil heart is a dead heart'. uncertain. This can also be seen in the different ways it is translated. Toy (1914:430) proposes a possible translation to read as follows: 'as he reckons within himself, so is he'. Longman (2006:425) adheres to the translation of the New Revised Standard Version (NRSV): 'For it is like a hair in the throat'. In turn, Geisler and Rhodes (1997:73) rest with the translation of the New International Version (NIV), which reads: 'He is the kind of man who is always thinking about the cost'. None of these different translations can support the teaching of the law of attraction.

Apart from the difficulties concerning the translation, it is clear that verse 7 must be interpreted together with verses 6 and 8 . Proverbs 23:1-3 give advice about table manners with a ruler, whereas verses 6 to 8 give advice about eating with a stingy person (Longman 2006:425). Geisler and Rhodes (1997) explain the whole context of this passage as follows:

The whole context of this passage (vv. 6-8) is warning about eating 'the bread of a miser' (v. 6). Speaking of the miser, the last verse says, "Eat and drink", he says to you, but his heart is not with you.' This fits with the idea that the miser's heart is not there because 'he is always thinking about the costs', as the NIV translates it. (p. 73)

Boshoff's (2010b) exposition of this passage is totally foreign to it. Proverbs 23:7 does not support the law of attraction in any way. It says nothing about changing one's reality through thoughts (Geisler \& Rhodes 1997:73).

\section{Does Matthew 12:33-35 support the law of attraction?}

Matthew 12:33-35 functions as a key text in Scripture for Boshoff (2010a, 2010b, 2010d) in his attempt to support the law of attraction. The heart is considered to be the centre of a person's being and following Matthew 12:33-35, the mouth will speak accordingly (Hagner 1998:350; Hendriksen \& Kistemaker 2001:350). The New Testament usage of the word 'heart' agrees with the Old Testament use thereof, for it is seen as a person's main organ of spiritual life. It is the seat of understanding and the source of thought and reflection (Kittel, Bromiley \& Pitkin 1964:611-612). But does this mean that one's entire life flows forth from one's heart and that the things one cherishes in one's heart, one will always attract to oneself, as Boshoff (2010b, 2010d) claims? Boshoff (2010b, 2010d) even replaces the words 'good' and 'evil' in verse 35, with 'positive' and 'negative' to try to bring his ideas into the text so that it reads: 'A positive man out of the positive treasure of his heart brings forth positive things, and a negative man out of the negative treasure brings forth negative things'.

Hagner (1998:350) mentions that the point being made in Matthew 12:33-35 is the same as in Matthew 7:17. A good tree automatically produces good fruit whereas a bad tree automatically produces bad fruit. The conclusion is therefore obvious in the sense that a tree is known by the kind of fruit it produces.

Blomberg (1992:205), Calvin (2010b:79), Hagner (1998:350), and Hendriksen and Kistemaker (2001:530) are all in accord 
that Jesus in Matthew 12:33-35 is addressing the Pharisees and applying the similarity between the tree and the fruit to nothing more than one's heart and speech. Hendriksen and Kistemaker (2001) write:

As a teeming population will overflow into adjoining territory, and a too full cistern into an overflow pipe, so also the overplus of the heart will burst out into speech, as it certainly did in the case of these wicked Pharisees. The opposite is also true: when the heart is filled with good and noble intentions the good man's speech will prove this to be a fact. The rule according to which whatever a man has set his heart on, so that the very core and center of his being is full of it, will sooner or later be disclosed in his speech, holds for good and bad alike. (p. 530)

When Jesus calls the Pharisees a 'brood of vipers' it is a clear indication that he believes the Pharisees to represent the bad tree with its bad fruit (Blomberg 1992:205). Therefore they are described as being incapable of speaking good things, because their bad speeches are indications of bad hearts (Blomberg 1992:205; Calvin 2010b:80; Hagner 1998:350; Hendriksen \& Kistemaker 2001:530).

It is clear from the pericope that the word 'treasure' in verse 35 is used figuratively, referring to the inner store of a person's heart. In the New Testament this word is normally used in situations where there is a contrast between heavenly and earthly treasures (see Mt 6:19-21). In this way Jesus uses the Jewish teaching that man should not assemble earthly and material things, but rather do good deeds, by which the righteous layup treasure in heaven (Kittel et al. 1964:137).

The verb 'brings forth' in verse 35 can hardly be applied to anything other than a person's words. Sayings of Boshoff (2010a, 2010b, 2010d) such as 'sending out an invisible signal', 'from within you release the energy that attracts things and people to you all the time', '... what is in your heart you're attracting into your life all the time whether you like it or not' and 'Your heart is going to attract to you' is once again foreign to Matthew 12:33-35. Calvin (2010b) already describes the purpose of this passage in his day as follows:

We must also observe the purpose for which Christ employs those parables; for he reproaches the Pharisees with having manifested by words the malice which they had inwardly conceived. Besides, knowing them to be sworn enemies, he takes occasion from a single calumny to expose their whole life, and to destroy their credit with the people, which gave them too great influence in deceiving and in doing mischief. Though good speeches do not always proceed from the inmost heart, but originate (as the phrase is) on the tip of the tongue, yet it is an invariable truth, that bad speeches are indications of a bad heart. (pp. 80-81)

Matthew 12:33-35 clearly does not support the law of attraction. It is not supporting the idea that the use of words can attract good or bad material things into one's life. When reading Matthew 12:33-35 together with verse 36 and 37 that can be considered to be appended as a climax to the preceding verses, it is evident that the words of a person reflect his or her inner identity. Words, like deeds, are indicators of a person's discipleship of Jesus and relationship to his kingdom (Hagner 1998:350-351; Hendriksen \& Kistemaker 2001:531).

\section{Did Joseph use the law of attraction?}

According to Boshoff (2010c), Joseph used the law of attraction to attract the favour he received in Genesis 39:2-4. In the biblical account Potiphar, the officer of Pharaoh, bought Joseph from the Ishmaelites and Joseph served in his house as a slave. Potiphar saw that the Lord was with Joseph and so Joseph found favour in the sight of his master, who then made him overseer of his house.

The reference to success in Genesis 39:2 is merely stating God's grace in Joseph's life. The word describing Joseph as a 'successful' man is a verb in the original Hebrew. Theologically this verb emphasises that only God is the one who gives success. It follows that the success this passage is referring to is about the intended accomplishment in the different activities of life - in this case in the life of Joseph (VanGemeren 1997:804).

Mathews (2005:731-732) notes that the phrase: 'The Lord was with Joseph ...' occurs again in verse 21 . This draws an explicit parallel between Joseph's success in the house of Potiphar and his achievement in prison. One can conclude that Joseph's success must be connected to God's graceful presence in his life and not his own ability to attract favour and success. Wenham (1998:374) adds to this that the Lord's presence in his life also places the coming unfortunate events into perspective (see Gn 39:19-21). Despite the setbacks Joseph was about to face, God was always with him.

This understanding of Genesis 39 is also in accordance with the understanding of early protestant theologians. Calvin (2010d) rightly draws attention to the following principle in this narrative of Joseph:

How much more base is our ingratitude, if we do not refer all our prosperous events to God as their author; seeing that Scripture often teaches us, that nothing proceeding from men, whether counsels, or labours, or any means which they can devise, will profit them, except so far as God gives his blessing. (p. 293)

Boshoff (2010c) sets a condition to his listeners when applying this passage to them: Just as Joseph attracted this success and favour because he believed correctly and used the law of attraction correctly, so they can also attract success and favour using the law of attraction correctly and believe correctly.

Joseph's success and favour cannot be attributed to himself through using the law of attraction in the correct way. When reading Genesis 39 it is rather clear that he did not attract Potiphar's favour into his own life through using the law of attraction. It was God's gracious act to provide it for him in his circumstances. God sovereignly set the course for Joseph to receive this success and favour, in the midts of a lot of hardship and unfair rulings.

Using the law of attraction through the correct way of believing to channel prosperity into existence cannot be called faith. Faith is rather a channel of living trust between a creature and his Creator (Hanegraaff 2009:277). 


\section{Evaluation of the doctrinal implications of the law of attraction}

\section{The dethronement of God}

The law of attraction refers to an all-powerful, impersonal, unbiased and universal law that determines every moment of one's entire life by responding to one's words and thoughts (Byrne 2006:5, 7, 13; Gray 2015:29-30; Hicks \& Hicks 2006:32). According to Pastor Boshoff and other proponents, it is up to you to make sure that one thinks and speaks positively to attract good things or circumstances into one's life. When bad things happens to you, it is your own doing because your negative thoughts and words attracted these bad things or circumstances (Boshoff 2010a; Byrne 2006:7,9; 2010:15; Che 2010:16; Lester 2008:2,10; Rinaldi 2008:11).

Because everyone can use this universal law to create and dictate the course of their own lives with their thoughts and also with their words, the first doctrinal implication of the law of attraction is the dethronement of God. If one believes that the idea of the law of attraction is true, God cannot act on your behalf unless you visualise, speak and believe correctly. God is thus limited to a genie in service of people (Peters 2013). He cannot operate outside of the universal law of attraction because even he is governed by it (Hanegraaff 2009:119-121; Jones \& Woodbridge 2011:62). Accordingly, God must obey this spiritual law of attraction and deliver whatever human beings desire in life. The teaching of the law of attraction and similar ideas is a direct disregard of the sovereignty and omnipotence of God - it destroys the essentials of historical Christianity (Hanegraaff 2009:147; MacArthur 1992:350-351; McConnell 1995:140). Boshoff (2010a) starts with the assumption that our lives are governed by the law of attraction without even mentioning God in the sentence.

When it comes to the truth about God, Van Til (2008) rightly emphasises that one must appeal to his authoritative Word:

\begin{abstract}
My primary interest is now, as it always has been, to teach what the Bible contains as the infallible rule of faith and practice in the way of truths about God and his relation to man and the world. (p. 241)
\end{abstract}

In Revelation 1:8 God clearly makes himself known as 'the Almighty' (Bible 1982). When one considers Psalm 115:1-3, it is clear that God always does whatever he wants. He is therefore not governed by anything outside of himself especially not the plans in the heart of man (see Pr 21:1 and 19:21). Following Psalm 115:3, Calvin (2010c) warns one not to abuse the sovereignty of God:

That God can do whatsoever he pleaseth is a doctrine of great importance, provided it be truly and legitimately applied. This caution is necessary, because curious and forward persons, as is usual with them, take the liberty of abusing a sound doctrine by producing it in defence of their frantic reveries. And in this matter we daily witness too much of the wildness of human ingenuity. This mystery, which ought to command our admiration and awe, is by many shamelessly and irreverently made a topic of idle talk. If we would derive advantage from this doctrine, we must attend to the import of God's doing whatsoever he pleaseth in heaven and on the earth. (p. 334)

God is absolutely sovereign in his decisions and actions and it is not determined by anything outside of himself (Smith 2012:90; Van Genderen \& Velema 2008:183, 194). The greatness of his power and might is more than enough ground to praise him and there are many more passages from Scripture ${ }^{7}$ to support the absoluteness of God's almighty power, who certainly has the last say (Frame 2013:337). No man can force the hand of God using some formula or spiritual law. The Bible teaches the absolute sovereignty of God in the universe. The limit that the law of attraction places on God is not in accordance with the Bible and basic Christian understanding (McConnell 1995:140-141). Oliphint (2012:218) sums it up as follows: 'There is nothing outside of God that initially limits Him; nor is there anything that ever limits His essential character'.

\section{The enthronement of man}

According to proponents of the law of attraction human thoughts and words become reality (Atkinson 1906:4-5). Byrne (2006:7) describes the power inside every human being as an unfathomable magnetic power that reaches out from one's thoughts into the universe and attracts the things that are at the same positive or negative vibrational level (see also Hicks \& Hicks 2006:83; Proctor 2011). A person's predominant thoughts are responsible for everything that happens to him or her (Gray 2015:23; Haanel 1917:627; Hicks \& Hicks 2006:32-33). When explaining the law of attraction, Boshoff (2010a) emphasises that it is in the hands of human beings to create their own future.

Boshoff's (2010a) claim that we are creating our own future through the law of attraction rather seems like a way to invert the relationship between the Creator and the creature (Jones \& Woodbridge 2011:63). According to the law of attraction, humans can use thoughts to attract things into their lives (Boshoff 2010b). This gives humans the leading part in the universe, and the only part left for God to play is to meet all their needs, including good relationships, sound health, and financial gains (Jones \& Woodbridge 2011:63; Peters 2013). The teaching of the law of attraction dangerously exalts man to the extent where they can manipulate God to control their own future (Hanegraaff 2009:121).

The doctrinal implication of the law of attraction is thus the enthronement of man. It is theologically inevitable that a demotion of God leads to an exaltation of something in creation - mostly man (McConnell 1995:142). In Genesis 3:4-5 ${ }^{8}$ the serpent depicts God to be selfish and deceptive, trying to prevent Adam and Eve from achieving the same position as Elohim (Mathews 1996:236). Regarding this first sin of man,

7.Consider 2 Chronicles 20:6, Job 23:13, Psalm 24:7-8, Psalm 135:6, Proverbs 16:1 Isaiah 14:24-27; 43:13, Daniel 4:35, Mark 14:36, Ephesians 1:18-23 and Philippians 3:21.

8.You will not surely die. For God knows that in the day you eat of it your eyes will be opened, and you will be like God, knowing good and evil (Bible 1982). 
Van Genderen and Velema (2008:390) remark: 'Man sought to usurp God's position. He reached for God's crown and claimed what was only due God'. Mere humans as creatures of God can never claim to be like God or to play God's role in their own lives. The desire to do so was the sin that led to the fall in the first place (see Is 14:12-15; Peters 2013).

According to James 4:13-16 the future of human beings is in God's hands and someone must therefore not pretend to know more about it than what is revealed to us (Frame 2013:155, 670). The claim that we can create our own future rather seems like a secularised attempt to elevate man to the king of creation in God's place (Boshoff 2010a; Van Genderen \& Velema 2008:378). According to the Bible and basic Christian doctrine there is a very crisp line between us as God's creatures and God as our Creator'.

Scripture clearly indicates that there is only one God and that it is a sin to claim otherwise ${ }^{10}$. When writing with regard to the first commandment, Frame (2008:415) emphasises that it is a clear violation thereof when you trust in yourself, your own power and capabilities. In question and answer 95 of the Heidelberg Catechism, the answer to the question: 'What is idolatry?', is:

It is, instead of the one true God who has revealed Himself in His Word, or along with the same, to conceive or have something else on which to place our trust. (Schaff 1882:342)

To believe in the law of attraction is to place trust in something else than God. It gives man the power and capabilities to play god over their own lives and, instead of God, trusting their own plans, while any man's plans are totally contingent (Smith 2012:89-90). In the teachings of Jesus and the apostles it is emphasised time and again that the life of a Christian should always be a pursuit of God's will and not a strategy to get him to go along with theirs (MacArthur 1992:351). Our will, heart, plans and everything is in a state of total depravity according to the reformed understanding of the Gospel ${ }^{11}$. There is nothing in human beings worthy of any praise (Hanko 2012:114).

The law of attraction takes the glory of God and gives it to man. Contrary to the absolute humble dependence upon God what Paul for instance wrote about in Romans 11:33-36 ${ }^{12}$, the doctrine of the law of attraction turns people

9. Calvin (1845:49) expresses it clearly in his Institutes of the Christian religion (Peters 2013). 'So long as we do not look beyond the earth we are quite pleased with our own righteousness, wisdom, and virtue; we address ourselves in the most flattering own righteousness, wisdom, and virtue; we address ourselves in the most flattering terms, and seem only less than demigods. But should we once begin to raise our
thoughts to God, and reflect what kind of Being he is, and how absolute the perfection of that righteousness, and wisdom, and virtue, to which, as a standard, we are bound to be conformed, what formerly delighted us by its false show of righteousness will become polluted with the greatest iniquity; what strangely imposed upon us under the name of wisdom will disgust by its extreme folly; and what presented the appearance of virtuous energy will be condemned as the most miserable impotence. So far are those qualities in us, which seem most perfect, from corresponding to the divine purity'.

10.See Exodus 20:3-4, 2 Samuel 22:32, Psalm 50:1, Isaiah 44:6-8, Mark 12:29, Romans 16:27, 1 Corinthians 8:6, Ephesians 5:6, 1 Timothy 1:17; 2:5 and James 2:19.

11.See Genesis 6:5, Psalm 14:2-3, Isaiah 64:6, Jeremiah 17:9 and Ephesians 2:1-3.

12.Oh, the depth of the riches both of the wisdom and knowledge of God! How unsearchable are his judgments and his ways past finding out! For who has known away from God who makes all things possible, to themselves to create their own life according to their insight and own (selfish) will.

\section{God's all-encompassing providence and the question of suffering}

Another doctrinal implication to discuss concerns the doctrine of God's providence ${ }^{13}$. Boshoff's (2010a, 2010d) claim that the law of attraction governs our life, that we are creating our own future and that we live by the law of attraction seems directly opposed to the doctrine of God's providence (MacArthur 1992:350-351). God's providence refers to his most holy, wise, and powerful preserving and governing of all his creatures, and their actions (Frame 2013:141)

Boshoff (2010a) refers to seven passages in the Bible to support his claim that a materially prosperous and blessed life is always God's will for a Christian. According to him, Christians who still struggle in life and do not live such a blessed, prosperous life simply do not understand the law of attraction.

Piper (2010:24) explains that, on the one hand we may trust in the Lord to be our helper, because he will provide and protect us - there is thus a measure of prosperity he will give us. But on the other hand there is a line between trusting God for our needs and using God for our wants. The law of attraction rather seems like an attempt to use God for our wants, than trusting in his providence.

Most Christians trust God to gracefully provide for all of creation. They believe that in God they live and move and he gives them, day by day, life and breath and all things (see Ac 17:25). To trust God for everything means that someone can die in peace in the confidence that the One who gives and preserves life also takes it away again, and that God is the faithful Father of his children, even in suffering and death (Hanko 2012:93; Van Genderen \& Velema 2008:291).

According to Velarde (2007:5) the fatal flaw of the law of attraction is its inability to adequately solve the problem of suffering. If everything that comes into our life experience is the result of our ability to create our own future, then what is the explanation for those that have been raped, tortured or persecuted? Following the only logical outcome the law of attraction can provide, everyone always brings these bad things upon themselves. Boshoff's (2010a) claim that people who struggle in life do not understand the law of attraction implies that they are the cause of their own suffering and

(footnote 12 continues...

the mind of the LORD? Or who has become his counselor? Or who has first given to him, and it shall be repaid to him? For of him and through him and to him are all things, to whom be glory forever. Amen (Bible 1982).

13.Article 13 of the Belgic Confession of Faith reads as follows with regard to God's providence: 'We believe that the same God, after he had created all things, did not forsake them, or give them up to for une or chance, but that he rules and governs orsake them, or give the up to fortune or chance, but that he rules and govern a appointment, nevertheless, God neither is the author of, nor can be charged with, the sins which are committed. For his power and goodness are so great and incomprehensible, that he orders and executes his work in the most excellent and just manner even when the devil and wicked men act unjustly'. 
struggles in life. According to Velarde's (2007:5) opinion a view such as this is atrocious. It is the same as to claim that all Paul's imprisonments, hardships, hunger and afflictions were a direct result of his own negativity that he allowed to dwell in his thoughts (see 2 Cor 11:22-29). According to the law of attraction, Job, the righteous man (according to God himself - Job 1:8), brought all the tragedies in his life unto himself (Job 3:25).

Preaching prosperity through the law of attraction, as Boshoff (2010a, 2010b, 2010c, 2010d) does, conceals the fact of suffering in the Christian life and it does not provide any comfort for someone enduring suffering in whatever way (Piper 2010:26). More than the notion of material prosperity, the New Testament emphasises the fulfilment of one's calling amidst suffering ${ }^{14}$. Piper (2010:26-27) considers it a disservice if one does not tell young disciples of Christ about the necessity of suffering. He further explains that God has definitive purposes for suffering, which is crucial to know. One must indeed search very hard to find one person in the Old and New Testament that lived a pain-free life on account of their faith (Jones \& Woodbridge 2011:109; Van Genderen \& Velema 2008:289).

Jones and Woodbridge (2011) write the following with regard to suffering:

While the Bible does not present suffering as desirable, it likewise does not view suffering as a hindrance to God's plan of redemption. While a day is coming in the future in which there will be no more pain and suffering, Scripture teaches that in the current world trials are a tool that the Lord uses in order to foster the sanctification of His people. (p. 122)

There is no easy answer to the question of suffering, but the Christian faith, and specifically the doctrine of God's providence, is very unique regarding the incarnation of Christ. God himself took on flesh and voluntarily became part of human suffering. Christ is the only person in history who, without any sin, went through the pain of immense and unjust suffering. Therefore, when a believer suffers, the fact that the fellowship of suffering includes Christ, should be comforting (Jones \& Woodbridge 2011:119-120; Van Genderen \& Velema 2008:311). The implications of the law of attraction rob the Christian faith of this uniqueness.

God's sovereignty includes both what he does, as well as his allowance of events that he knows will happen. In his absolute sovereignty, God also uses suffering to accomplish his plans and conform his children to his image (Jones \& Woodbridge 2011:121). The apostle Paul writes in 2 Corinthians 4:17:

For our light affliction, which is but for a moment, is working for us a far more exceeding and eternal weight of glory, while we do not look at the things which are seen, but at the things which are not seen. For the things which are seen are temporary, but the things which are not seen are eternal. (Bible 1982)

According to Frame (2013:300) suffering should remind us of the sovereignty of God. When Job wanted to know from God 14.Consider Mathew 10:25, John 15:20, Acts 14:22, Romans 8:16-18, Ephesians 6:10ff., 1 Peter 4:12-14 and 2 Timothy 3:12. why such dreadful suffering came upon him, God asked Job a question: 'Where were you when I laid the foundations of the earth? Tell Me, if you have understanding'. (Job 38:4). An answer like this reveals the truth that God is sovereign even amidst suffering ${ }^{15}$. The deepest hope for the Christian is eternal, not in health, wealth and prosperity in this lifetime, but rather a resurrected body in the life to come. Christians have the certainty that their futures are in God's hands and not theirs, for we do not know what is best for us (Hanegraaff 2009:277-278).

\section{Evaluating the worldview behind the law of attraction}

The last doctrinal implication of the law of attraction to briefly evaluate is the worldview behind it. As noted in the first article (Part 1), the core worldview behind the law of attraction is a combination of pantheism and monism. Anderson (2014:81) notes that pantheism is very often associated with monism.

Within monism any diversity we experience is an illusion. Any distinctions that we make between things are only in the mind, because any distinction between things destroys the oneness of everything in monism. The implication is that any experience of the diverse world is unreliable because, either all the diverse things are indeed identical, or it is unreal. In this great oneness there is furthermore no fundamental difference between God and the world (Anderson 2014:71-72; Van Genderen \& Velema 2008:249; Velarde 2007:4).

At the heart of pantheism lies an impersonal god which can rather be described as a force or energy. If everything is a manifestation of God, then everything is good, like God ought to be. The implication is that the Holocaust was good, child abuse is good, cancer is good and everything is good because everything is God. Pantheism consequently raises serious questions when it comes to the reality of good and evil. The basis for this distinction disappears and evil is completely denied (Anderson 2014:81-82; Van Genderen \& Velema 2008:289; Velarde 2007:4).

When it comes to the basic Christian worldview ${ }^{16}$, it begins with God, but not with God as man wants him to be in his service. It begins with the God who is really there and that everything else is dependent on him. It is about him and not about the benefit of individual humans, compelled to be in a bigger or lesser extent, at the expense of others.

\section{Conclusion}

But there were also false prophets among the people, even as there will be false teachers among you, who will secretly bring in destructive heresies, even denying the Lord who bought them, and bring on themselves swift destruction. And many will follow

15. He (God) will turn to my good; for he is able to do it, being Almighty God, and willing also, being a faithful Father. Therefore '. we may be patient in adversity willing also, being a faithful Father. Therefore .... we may be patient in adversity thankful in prosperity, and for what is future have good confidence in our faithfu God and Father that no creature shall separate us from His love ...' (Schaff
1882:316).

16.Ryken $(2006: 13,15)$ describes the basic Christian worldview as a God-given, Biblebased, Christ-centred worldview, which begins with the person who is the notsilent God. 
their destructive ways, because of whom the way of truth will be blasphemed. (Bible 1982; 2 Pt 2:1-2)

These are the words of the apostle Peter, which are not only meant for the church of his time, but, under the inspiration of the Holy Spirit, for the true church of Christ throughout the ages. It is these and similar words that inspired the New Testament church through centuries to look apologetically to those in her midst that deviate from the true Scriptural understanding of Christian doctrines (Edgar \& Oliphint 2009, 2011)

With regard to 2 Peter 2:1, Calvin (2010a) writes:

As to the word opinions or heresies, it has not, without reason, been always deemed infamous and hateful by the children of God; for the bond of holy unity is the simple truth. As soon as we depart from that, nothing remains but dreadful discord. (p. 393)

Oliphint (2013:29) explains that Christian apologetics is the application of biblical truth to unbelief and that there have been, are, and will continue to be attacks of every sort that seek to destroy the truth of the Christian faith ${ }^{17}$.

Van Genderen and Velema (2008:1) start their book, Concise Reformed Dogmatics, expressing that there will be times when dogmatics are in demand, but also some periods when sound and consistent biblical doctrine is not highly regarded. It seems that the latter description is an accurate description of the time in which we find ourselves when we consider spiritual teachings such as the law of attraction.

Serious attention was given to the sermons of At Boshoff on the law of attraction, to show that secularised practices are infiltrating the Christian church, with far-reaching doctrinal implications that threaten some of the fundamental tenets of historical Christianity. The conclusion of the first, and especially second article can be no other than the Bible and Christian worldview makes no place for an impersonal law such as the so-called law of attraction, that even governs and limits the almighty God of heaven and earth. To teach something that limits the almighty God is heresy ${ }^{18}$. Hanegraaff (2000) describes it as follows:

What we are dealing with is the way in which secular religion manifests itself in the context of the Christian churches. This is a phenomenon too important to be passed over lightly. (p. 311)

It is not the law of attraction that governs our lives according to the Bible, but God. We do not create our own future

\footnotetext{
17.This article will work with Oliphint's definition of apologetics. There are many different ways to define apologetics. When discussing the essence of apologetics, McGrath (2012:16) for instance emphasizes that apologetics helps to open the eyes of people to the reality, reliability, and relevance of the Christian faith and that the task of apologetics still continues today as new cultural and intellectual challenges arise.

18.When discussing 2 Peter 2:1, Kistemaker and Hendriksen (2001:281) wrote: 'The word heresies derives from the Greek verb which signifies to take something for one's self, to choose, or to prefer. It refers to a chosen course of thought or action that an individual takes or that a group of people adopts as an article of faith or way of life. The inevitable result is the act of separation which gives the term way of life. The inevitable result is the act of separation which gives the term
heresy an unfavorable connotation ... What is the result? Peter leaves no doubt heresy an unfavorable connotation ... What is the result? Peter leaves no doubt secretly introduce destructive heresies'. The literal reading is, 'heresies of [for] secretly introduce destructive heresies'. The literal reading is, 'heresies of [for]
destruction'. The false teachers, then, slyly entered the Christian community with destruction'. The false teachers, then, slyly entered the Christian community with
doctrines designed to destroy the spiritual and moral lives of the Christians'.
}

through manipulating things with our minds; our future is safe in the hands of God alone. We do not live by the simple law of attraction; we live only by the grace of our heavenly Father.

\section{Acknowledgements Competing interests}

The authors declare that they have no financial or personal relationships which may have inappropriately influenced them in writing this article.

\section{Authors' contributions}

D.J.M. is the author and H.G.S. is the co-author.

\section{References}

Anderson, J.N., 2014, What's your worldview?: An interactive approach to life's big questions, Crossway, Wheaton, IL.

Atkinson, W.W., 1906, Thought vibration or the law of attraction in the thought world, New Thought, Chicago, IL.

Bible. 1982, The new King James version, Thomas Nelson, Nashville, TN.

Blomberg, C., 1992, The new American commentary, Volume 22: Matthew, Broadman \& Holman, Nashville, TN.

Boshoff, A., 2010a, The law of attraction Part 1 -1/3, viewed 17 February 2105, from https://www.youtube.com/watch?v=Ed9F38bjLy8

Boshoff, A., 2010b, The law of attraction Part $1-2 / 3$, viewed 17 February 2105, from https://www.youtube.com/watch?v=060AmCjfxRk

Boshoff, A., 2010c, The law of attraction Part 1 -3/3, viewed 17 February 2105, from https://www.youtube.com/watch?v=qTSseZridbg

Boshoff, A., 2010d, The law of attraction Part 2-01 of 03, viewed 17 February 2105 from https://www.youtube.com/watch?v=gmMqKNbZM50

Byrne, R., 2006, The secret, Beyond Words, Hillsboro, OR.

Byrne, R., 2010, The secret: The power, Atria Books, New York, NY.

Calvin, J., 1845, Institutes of the Christian religion, transl. H. Beveridge, The Calvin Translation Society, Edinburgh.

Calvin, J., 2010a, Commentaries on the Catholic epistles, transl. J. Owen, Logos Bible Software, Bellingham, WA.

Calvin, J., 2010b, Commentary on a harmony of the evangelists Matthew, Mark and Luke, transl. J. Owen, Logos Bible Software, Bellingham, WA.

Calvin, J., 2010c, Commentary on the book of the Psalms, transl. J. Owen, Logos Bible Software, Bellingham, WA.

Calvin, J., 2010d, Commentary on the first book of Moses called Genesis, transl. J. King Logos Bible Software, Bellingham, WA.

Carson, D.A. \& Keller, T. (eds.), 2012, The Gospel as centre: Renewing our faith and reforming our ministry practices, Crossway, Wheaton, IL.

Che, D., 2010, Total law of attraction: Unleash your secret creative power to get what you want!, Gallery Books, New York, NY.

CRC (Christian Revival Church). 2015a, Welcome to CRC, viewed 14 May 2015, from http://www.crc.org.za/

CRC (Christian Revival Church). 2015b, Statement of faith, viewed 24 September 2015, from http://www.crc.org.za/

CRTA. 2015, The Chicago statement of biblical inerrancy, viewed 10 May 2016, from http://www.reformed.org/bible/index.html

Edgar, W. \& Oliphint, K.S., 2009, Christian apologetics: Past and present, Volume 1: to 1500, Crossway, Wheaton, IL.

Edgar, W. \& Oliphint, K.S., 2011, Christian apologetics: Past and present, Volume 2 from 1500, Crossway, Wheaton, IL.

Frame, J.M., 2008, The doctrine of the Christian life, P \& R, Phillipsburg, NJ.

Frame, J.M., 2013, Systematic theology: An introduction to Christian belief, P \& R, Phillipsburg, NJ.

Garret, D.A., 1993, The new American commentary, Volume 14: Proverbs, Ecclesiastes, Song of Songs, Broadman \& Holman, Nashville, TN.

Geisler, N.L. \& Rhodes, R., 1997, When cultists ask: A popular handbook on cultic misinterpretations, Baker Books, Grand Rapids, MI.

Gray, S., 2015, Law of attraction: Unleash the power and be the creator of your life, Great Reads, LLC.

Haanel, C.H., 1917, 'The master key system', in N. Hill (ed.), The prosperity Bible: The greatest writings of all time on the secrets to wealth and prosperity, 2007, pp. 595-728, Tarcher/Penguin, New York, NY. 
Hagner, D.A., 1998, Word Biblical commentary, Volume 33A: Matthew 1-13, Word Books, Dallas, TX.

Hanegraaff, H., 2009, Christianity in crisis: 21st century, Thomas Nelson, Nashville, TN.

Hanegraaff, W.J., 2000, 'New Age religion and secularization', Numen 47(3), 288-312. $\mathrm{http}: / /$ dx.doi.org/10.1163/156852700511568

Hanko, R., 2012, Doctrine according to Godliness: A primer of reformed doctrine, 2nd edn., Reformed Free Publishing Association, Jenison, MI.

Hendriksen, W. \& Kistemaker, S.J., 2001, New Testament commentary: Exposition of the gospel according to Matthew, Baker Book House, Grand Rapids, MI.

Hicks, E. \& Hicks, J., 2006, The law of attraction: The basics of the teachings of Abraham, Hay House, Carlsbad, CA.

Jones, D.W. \& Woodbridge, R.S., 2011, Health, wealth \& happiness: Has the prosperity gospel overshadowed the gospel of Christ? Kregel, Grand Rapids, MI.

Keil, C.F. \& Delitzsch, F., 1996, Commentary on the Old Testament, Hendrickson, Peabody, MA.

Kidner, D., 1964, Tyndale Old Testament commentaries, Volume 17: Proverbs, an introduction and commentary, InterVarsity Press, Downers Grove, IL.

Kistemaker, S.J. \& Hendriksen, W., 1953-2001, New Testament commentary, Volume 16: Exposition of the epistles of Peter and the epistle of Jude, Baker Book House, Grand Rapids, MI.

Kittel, G., Bromiley, G.W. \& Pitkin, R.E. (eds.), 1964, Theological dictionary of the New Testament, WM.B. Eerdmans, Grand Rapids, MI.

Lange, J.P., Schaff, P., Zöckler, O. \& Aiken, C.A., 2008, Lange's commentary on the Holy Scriptures, Volume 18: Proverbs, Logos Bible Software, Bellingham, WA.

Lester, M., 2008, The everything law of attraction book: Harness the power of positive thinking and transform your life, Adams Media, F+W, Avon, MA.

Longman, T., 2006, Proverbs: Baker commentary on the Old Testament wisdom and Psalms, Baker Academic, Grand Rapids, MI.

MacArthur, J.F., 1992, Charismatic chaos, Zondervan, Grand Rapids, MI.

Mathews, K.A., 1996, The new American commentary, Volume 1A: Genesis 1-11:26, Broadman \& Holman, Nashville, TN.

Mathews, K.A., 2005, The new American commentary, Volume 1B: Genesis 11:27-50:26, Broadman \& Holman, Nashville, TN.

McConnell, D.R., 1995, A different gospel, Hendrickson, Peabody, MA.

McGrath, A.E., 2012, Mere Apologetics: How to help seekers and skeptics find faith, Baker Books, Grand Rapids, MI.
Murphy, R.E., 1998, Word Biblical commentary, Volume 22: Proverbs, Thomas Nelson, Nashville, TN.

Oliphint, K.S., 2012, God with us: Divine condescension and the attributes of God, Crossway, Wheaton, IL.

Oliphint, K.S., 2013, Covenantal apologetics: Principles and practice in defense of our faith, Crossway, Wheaton, IL.

Peters, J., 2013, Clouds without water: A biblical critique of the Word of Faith movement. Exposing the false prosperity gospel produced by Justin Peters Productions, Justin Peters Ministries, Edmond, OK. [DVD].

Piper, J., 2010, Let the nations be glad: The supremacy of God in missions, 3rd edn., Baker Academic, Grand Rapids, MI.

Proctor, B., 2011, 'Bob Proctor on The Secret, the law of attraction and vibration', viewed 03 August 2015, from https://www.youtube.com/watch?v=ouUZN9QvRjA

Rinaldi, S., 2008, The Metaphysician's Guide to using the law of attraction: Designing your life with the power of thought, Karma Center, Great Barrington, MA.

Ryken, P.G., 2006, What is the Christian worldview: Basics of the faith series, P \& R, Phillipsburg, NJ.

Schaff, P., 1882, The creeds of Christendom, with a history and critical notes, Volume III: The Evangelical Protestant creeds, with translations, 3rd edn., Harper, New York, NY.

Sire, J.W., 2009, The universe next door: A basic worldview catalog, InterVarsity Press, Downers Grove, IL.

Smith, C.S., 2012, 'The plan', in D.A. Carson \& T. Keller (eds.), The Gospel as centre: Renewing our faith and reforming our ministry practices, pp. 89-113, Crossway, Wheaton, IL.

Toy, C.H., 1914, A critical and exegetical commentary on the book of Proverbs, T. \& T. Clark, Edinburgh. (The international critical commentary on the Holy Scriptures of the Old and New Testaments).

VanGemeren, W.A. (ed.), 1997, New International dictionary of Old Testament theology \& exegesis, Zondervan, Grand Rapids, MI.

Van Genderen, J. \& Velema, W.H., 2008, Concise Reformed dogmatics, transl. G. Bilkes \& M. Van der Maas, $P$ \& R, Phillipsburg, NJ.

Van Til, C., 2008, The defense of the faith, 4th ed., in K.S. Oliphint (ed.), P \& R, Phillipsburg, NJ.

Velarde, R., 2007, 'The Secret revealed: Assessing the latest self-help phenomenon', Christian Research Journal 30(6), 1-6.

Wenham, G.J., 1998, Word Biblical commentary, Volume 2: Genesis 16-50, Thomas Nelson, Nashville, TN. 